Maximilian Buchholz, Harald Bathelt*

\title{
Models of Regional Economic Development: Illustrations Using U.S. Data
}

https://doi.org/10.1515/zfw-2020-0040

Received: 25. November 2020; accepted: 30. March 2021

\begin{abstract}
Considering stagnating regional prosperity levels and growing inter-regional disparities in many economies, this paper appeals for a renewed research agenda to deepen our understanding of regional economic development. This is done by discussing different conceptual perspectives, their empirical applications and open questions and suggestions for future research. Conventional approaches view development as an outcome of and dependent upon local economic structure. That is, high regional performance is associated with specific regional industrial and human capital mixes. We argue that to deepen our understanding of the mechanisms that drive regional economic development it is helpful to apply a relational approach that pays attention to the networks between economic actors across different spatial scales, from local to global. These generate knowledge as well as access to technologies, resources and markets, thereby catalyzing income growth. To support regional policy agendas, it is further necessary to go beyond identifying regularities that structure development and engage with differing regional pathways by conducting systematic comparative analyses of local contextual and institutional conditions.
\end{abstract}

Keywords: geographical context; industrial structure; human capital; relational perspective; regional economic development; United States

JEL codes: F21; F23; R11

\section{Introduction}

How to promote economic development in stagnating or declining city-regions is an issue that has long been on the agenda of economic geographers and regional econ-

*Corresponding author: Harald Bathelt, University of Toronto, Department of Geography \& Planning, Sidney Smith Hall, 100 St. George Street, Toronto, ON, M5S 3G3, Canada, e-mail: harald.bathelt@utoronto.ca

Maximilian Buchholz, University of Toronto, Department of Geography \& Planning, Sidney Smith Hall, 100 St. George Street, Toronto, ON, M5S 3G3, Canada, e-mail:max.buchholz@mail.utoronto.ca omists (Pike et al., 2011) but has received renewed attention due to increasing disparities in income and employment opportunities within many national urban systems (Dannenberg et al., 2018; Nijman \& Wei, 2021). Populist voices link lagging regional economic growth or decline to global trade patterns and international immigration waves (see the analyses by Storper, 2018; Parnreiter, 2018; Spicer, 2018). While such implications are often not supported by empirical evidence, the rise of these voices reminds us that our knowledge of the very mechanisms and processes that influence regional economic development is partial at best and that collective efforts in the social sciences are necessary to fill existing gaps. Combating rising stagnation and decline in turn requires that we improve our models of how to promote economic development within city-regions.

This paper aims to contribute to deepening our understanding of regional economic development by discussing different models and their shortcomings. Research increasingly points to the need to consider well-being more precisely in our measurement of economic development (Kubiszewski et al., 2013; Schmid, 2019), as well as who exactly benefits from regional growth (Benner \& Pastor, 2015; Florida, 2017; Kemeny \& Storper 2020). While we agree that such debates are crucial, in this paper we operationalize regional economic development in terms of the average income and employment opportunity within city-regions, as these are systematically linked to a wide range of outcomes (Moretti, 2012) and are an important starting point for reducing inequality. We argue that relational approaches and systematic contextual analyses can help resolve some of these issues and advance our understanding of development. This is done by presenting the findings of empirical studies on urban-regional development in the United States where some city-regions have experienced persistent improvements in economic development levels over the last few decades, while others have been stagnant (Buchholz et al., 2020).

Many standard approaches to regional economic development can be characterized as regional endowment models that try to link development levels to specific economic structures and endowments of human capital, localized resources and capabilities (Rosenthal \& Strange, 2004; Glaeser \& Gottlieb, 2009). While there are many 
approaches to modeling regional economic development, two particularly influential strands of research focus on the impact of preexisting capital (industrial structure) and labor (human capital/skills) endowments. The argument underlying these approaches is that regions with strong economic performance are characterized by large shares of college-educated workers (Giannone, 2017; Moretti, 2004), a strong economic basis in terms of labor market characteristics and industrial mix (Marchand et al., 2020) and/ or a set of related industries that are closely linked and support each other (Frenken et al. 2007). Empirical studies have supported such associations but findings regarding the underlying mechanisms that stimulate development are inconclusive and lead to open questions. Essentially, these approaches focus on structure while paying less attention to economic action and interaction (Giddens, 1984; Clark, 2018; 2021). The argument developed in this paper is that it is important to pay attention to the ways in which regional economies are embedded in networks of relationships with other economic actors across different spatial scales, ranging from local to global, through which growth triggers can be stimulated and transmitted (Zhu et al., 2017; Bathelt \& Buchholz, 2021). Structural conditions can play an important role in mediating the quality and importance of such relationships, but can hardly be used to explain development on their own. It is through such a perspective that we try to resolve the dualism of structure and agency. We view this as an important step in understanding the processes that shape development.

To explain why regional development paths may differ despite similar structural or relational characteristics or why different pathways are equally successful despite different features, we need to understand how regional contexts and institutional settings can overcome structural and relational limitations. Our appeal is therefore not to end statistical investigations with the identification of regularities between dependent and independent variables (see, also, Bathelt \& Li, 2020; Rutten, 2020). Instead, we support the need for more research that takes another step in understanding differences in economic development by engaging in systematic comparative analyses of the contextual and institutional influences, as well as individual actions, in specific geographical cases (Pike, 2021). We illustrate this by providing examples of how locally contingent factors can shape high or low levels of economic growth in selected regional cases.

The rest of this paper proceeds as follows. Section 2 introduces approaches that view regional economic performance as a function of prior industrial structure (capital) and identifies open questions while section 3 conducts a similar analysis for human capital (labor) approaches.
Section 4 shows that a relational perspective of regional economic development can fill some of the gaps left open by the industrial structure and human capital approaches. This perspective focuses on economic linkages and connections within and across territories that can stimulate regional economic development as they support the creation of new ideas and link local economies with spatially separated resources, technologies and markets. Section 5 argues that any such modelling of regional development must take into consideration the localized institutional and contextual conditions that can create specific triggers for growth or decline. Section 6 concludes and emphasizes the need for a systematic comparative research agenda in the future.

\section{Industrial Structure and Regional Performance}

Researchers widely agree that differences in industrial composition are associated with different levels of regional economic development. What is less agreed upon is exactly what mix of industries and localized resources at the regional level best promotes economic growth. Past statistical analyses have investigated whether higher levels of regional industrial specialization or a more diverse industrial structure will generate higher regional prosperity levels. One particularly influential paper is Glaeser et al.'s (1992) study of economic growth in U.S. cities, in which they test whether Jacobs (1969), Marshall-ArrowRomer (Arrow, 1962; Marshall, 1920; Romer, 1986) or Porter (1990) externalities best explain regional economic growth. Glaeser et al. (1992) suggest that if Jacobs externalities are most important, then regional economic growth will be strongly associated with industrial diversity and local competition, whereas if Marshall-Arrow-Romer externalities are most important, industrial specialization and local monopoly are key. Finally, Porter externalities will be most important if industrial specialization and local competition drive growth.

To test these propositions, Glaeser et al. (1992) ran a linear regression model, in which they included indicators for each type of externality. As dependent variables, they used the growth of employment and per-capita wage and salary income for each of 170 Standard Metropolitan Areas' 6 largest 2-digit SIC industries between 1956 and 1987 (which adds up to 1,020 2-digit SIC city-industry pairs - although the number of observations in Table 1 is slightly lower due to missing data). Key independent variables in Glaeser et al.'s (1992) model included indicators 
Table 1: Determinants of Employment and Per-Capita Wage Income Growth in U.S. Cities According to Glaeser et al. (1992), Cross-Sectional Effects

\begin{tabular}{|c|c|c|c|}
\hline \multicolumn{2}{|c|}{ Independent Variables } & $\begin{array}{l}\text { log(Employment } 1987 \text { / } \\
\text { Employment 1956) for a } \\
\text { City-Industry } \\
\text { (1) }\end{array}$ & $\begin{array}{l}\text { log(Income } 1987 \text { / Income } \\
\text { 1956) for a City-Industry } \\
\text { (2) }\end{array}$ \\
\hline Specialization & $\begin{array}{l}\text { City-Industry's Share of City } \\
\text { Employment Relative to Industry's Share of } \\
\text { U.S. Employment, } 1956\end{array}$ & $\begin{array}{c}-0.008^{\star * *} \\
(0.003)\end{array}$ & $\begin{array}{r}-0.000 \\
(0.001)\end{array}$ \\
\hline Competition & $\begin{array}{l}\text { Establishments per Employee in a } \\
\text { City-Industry Relative to Establishments per Employee } \\
\text { in the U.S. Industry, } 1956\end{array}$ & $\begin{array}{l}0.561^{\star \star \star} \\
(0.057)\end{array}$ & $\begin{array}{c}-0.085^{\star \star \star} \\
(0.014)\end{array}$ \\
\hline Inverse & City’s Other Top Five Industries' & $-0.913^{\star \star \star}$ & $-0.161^{\star \star \star}$ \\
\hline Diversity & Share of Total City Employment, 1956 & $(0.245)$ & $(0.059)$ \\
\hline . & . & . & . \\
\hline . &. & . & $\cdot$ \\
\hline Adjusted $R^{2}$ & & 0.450 & 0.414 \\
\hline Observations & (City-Industries) & 1,016 & 833 \\
\hline
\end{tabular}

Notes: Linear cross-sectional regression analysis - units of analysis are 2-digit SIC industries in 170 U.S. Standard Metropolitan Areas. Column 1 corresponds to column 4 of Table 3 in the original paper while column 2 corresponds to column 4 of Table 4. Other controls for the growth in each industry's employment at the national level, the wage and employment in a city-industry in 1956 and an indicator for whether a city is located in the South are not included in the table. Standard errors are reported in parentheses. ***, ** and * correspond to p-values less than $0.01,0.05$ and 0.10 , respectively.

Source: Glaeser et al. (1992).

of specialization/diversity and competition/monopoly in 1956. The main findings of their analysis are reported in Table 1. As shown in column 1, the results for employment growth rates suggest that city-industries with more local competition and higher industrial diversity (defined as less specialization) in 1956 grew faster between 1956 and 1987, while those city-industries that were more concentrated in a particular location (defined as specialized) grew slower. In the case of per-capita income in column 2, industrial diversity and local monopoly appear to best promote growth. From this analysis, the authors conclude "that at the city-industry level, specialization hurts, competition helps, and city diversity helps employment growth" (p.1150).

Another more recent body of work uses indicators of "related" and "unrelated variety" to explain differences in economic development based on local industrial structure. Initially developed by Frenken et al. (2007), studies in this approach argue that diversity at high levels of industry aggregation can be viewed as an indicator of "unrelated variety" of the local industry base. It is argued that such unrelated variety does not spur regional economic growth. Instead, it is suggested that the existence of a large number of related industries (i.e. "related variety"), as measured at more disaggregated industry levels, can best generate economic growth. Unrelated variety in a city is generally measured by an entropy index over all industries in a city (e.g. at the 2-digit SIC level), thus capturing the diversity of employment at an aggregate level. In a similar way, an entropy index is calculated within each 2-digit industry (based on 3-digit or more fine-grained SIC levels) and then these 2-digit entropy scores are added up, weighted by their share of total city employment. The resulting indicator is interpreted as a measure of related variety that captures how much variety exists on average within a city's 2-digit SIC industries. Frenken et al. (2007) argue that related variety should be expected to drive regional employment growth, as it spurs the creation of new markets and related employment. It is further suggested that productivity growth, unlike employment growth, is driven by specialization effects (i.e. localization economies), as specialization results in incremental productivity-enhancing process innovations. Finally, population density is seen as a measure that captures the extent of urbanization economies which benefit firms and workers when locating in a large city. Frenken et al. (2007) expect that the latter indicator is positively associated with economic development.

Research on related variety often uses a model formulation similar to Glaeser et al. (1992), although computed at the city rather than the city-industry level. In such models, related and unrelated variety in a base year are used as 
Table 2: Determinants of Employment and Productivity Growth in Dutch Cities and Regions According to Frenken et al. (2007), Cross-Sectional Effects

\begin{tabular}{lll}
\hline \multicolumn{1}{c}{ Dependent Variables } & $\begin{array}{l}\text { \% Employ- } \\
\text { ment Growth } \\
\text { 1996-2002 }\end{array}$ & $\begin{array}{l}\text { \% Productivity } \\
\text { Growth 1996-2001 }\end{array}$ \\
Independent Variables & $\mathbf{( 1 )}$ & $\mathbf{( 2 )}$ \\
\hline Unrelated Variety & -0.045 & -0.061 \\
& $(0.160)$ & $(0.121)$ \\
Related Variety & $0.638^{\star \star \star}$ & $-0.273^{\star \star}$ \\
Los-Index (Localization & -0.124 & $(0.123)$ \\
Economies) & $(0.168)$ & -0.084 \\
Log Population Density & -0.266 & $(0.130)$ \\
& $(0.188)$ & -0.092 \\
. & $\cdot$ & $(0.143)$ \\
. & $\cdot$ & $\cdot$ \\
Adjusted R & $\cdot$ & $\cdot$ \\
Observations & 0.424 & 0.571 \\
\hline
\end{tabular}

Notes: Linear cross-sectional regression analysis - units of analysis are Dutch cities and regions (NUTS 3 level). Column 1 corresponds to column 1 of Table 1 in the original paper while column 2 corresponds to column 1 of Table 2. Other controls for column 1 above include investments and R\&D spending per full-time worker. Column 2 adds the capital-labor ratio growth as a control as well. Standard errors are reported in parentheses. ${ }^{* \star *},{ }^{* *}$ and * correspond to $p$-values less than $0.01,0.05$ and 0.10 , respectively.

Source: Frenken et al. (2007).

independent variables to predict economic development between the base year and a future time period (e.g. Boschma \& Iammarino, 2009; Bishop \& Gripaios, 2010). In the case of Frenken et al.'s (2007) study, employment and productivity changes were modeled across Dutch NUTS 3 regions (yielding a relatively small number of observations) using 1996 as the base year to predict employment (1996-2002) and productivity (1996-2001) growth rates. The main results are reported in Table 2. Notably, Frenken et al. (2007) found that high local related variety in the base year had a positive association with regional employment growth and a negative association with productivity growth. Not shown in Table 2, some evidence was found that unrelated variety provided insurance against unemployment growth. Ultimately, Frenken et al. (2007, p. 696) argued that "related variety in cities is responsible for job creation and not urban density in itself". The concepts and findings from this work have stimulated a large literature on related and unrelated variety (Content \& Frenken, 2016), and have influenced the policy literature, for instance linking it to the concept of smart specialization (Balland et al., 2019). As argued below, these models are characterized by linking regional development to localized industrial structure and by prioritizing structure over agency in their explanation.

The above models leave several open questions regarding modeling regional economic development as a function of industrial structure. For one, while these studies emphasize regional industrial diversity as an optimal structure to promote economic development, this relationship is far from clear. Kemeny \& Storper (2015), for instance, argue that the emphasis on relative specialization (i. e. the share of employees in a particular industry) in prior research over measures of absolute specialization (the sum of employees in a particular industry) obscures the fact that benefits from specialization derive from the total economies of scale within a city-region's industries, rather than from their relative size. They also point out that even at a granular level (e.g. the 6-digit SIC industry level), there is significant heterogeneity in wage levels across regions. This suggests that even if policymakers were able to boost employment in a particular industry which typically has high income levels, there is no guarantee that this would have equally positive impacts across all regions. It is thus necessary to engage with a broader set of potential influences on regional economic development and consider why a particular industry might be of higher quality in some cities than others. In section 5, we will argue that specific institutional and contextual conditions can mediate the relationship between industrial structure and economic development. This includes opening up encapsulated regions to integrate development impulses from outside.

Another open issue is that while approaches focused on industrial structure do well at associating regional development with past industry structures, they are less focused on explaining what kinds of changes in fact prompt the observed shifts in development. Both studies discussed above, for instance, relate growth in regional income levels to structural indicators in a prior time period, but not to changes in those indicators. To illustrate this, Table 3 reproduces some of the analysis from the related variety literature for U.S. MSAs. Related and unrelated variety were calculated as defined by Frenken et al. (2007) using NAICS data from the Quarterly Census of Employment and Wages (U.S. Bureau of Labor Statistics, 2020). Columns 1 and 2 use Frenken et al.'s (2007) approach to draw an association between related and unrelated variety levels in the base year 2010 and changes in regional development indicators between 2010 and 2017 (using employment density as a control). Regional development is measured by (2017 inflation-adjusted) per-capita wage and salary income growth rates (a plausible indicator for 
Table 3: Impact of Industrial Structure on Per-Capita Income and Employment Development in U.S. MSAs (Metropolitan Statistical Areas), 2010-2017, Cross-Sectional and Longitudinal Effects

\begin{tabular}{|c|c|c|c|c|}
\hline Dependent Variables & $\begin{array}{l}\text { In(Per-Capita } \\
\text { Income) Growth } \\
\text { 2010-2017 } \\
\text { (1) }\end{array}$ & $\begin{array}{l}\text { In(Employment) } \\
\text { Growth 2010-2017 } \\
\text { (2) }\end{array}$ & $\begin{array}{l}\text { In(Per-Capita } \\
\text { Income) Change } \\
\text { 2010-2017 } \\
\text { (3) }\end{array}$ & $\begin{array}{l}\text { In(Employment) } \\
\text { Change 2010-2017 } \\
\text { (4) }\end{array}$ \\
\hline Intercept & $\begin{array}{r}-0.004 \\
(0.005)\end{array}$ & $\begin{array}{r}-0.016 \\
(0.010)\end{array}$ & $\begin{array}{l}0.034^{\star \star \star} \\
(0.003)\end{array}$ & $\begin{array}{l}0.099 \star \star \star \\
(0.009)\end{array}$ \\
\hline Related Variety 2010 & $\begin{array}{l}-0.001 \\
(0.001)\end{array}$ & $\begin{array}{l}0.004^{\star \star} \\
(0.002)\end{array}$ & & \\
\hline Unrelated Variety 2010 & $\begin{array}{l}0.003^{* * *} \\
(0.001)\end{array}$ & $\begin{array}{l}0.000 \\
(0.003)\end{array}$ & & \\
\hline $\begin{array}{l}\text { In(Employment Density) } \\
2010\end{array}$ & $\begin{array}{l}0.000 \\
(0.000)\end{array}$ & $\begin{array}{c}-0.001^{\star \star} \\
(0.001)\end{array}$ & & \\
\hline Related Variety Change & & & 0.003 & -0.022 \\
\hline $2010-2017$ & & & $(0.010)$ & $(0.036)$ \\
\hline Unrelated Variety Change & & & $-0.029 *$ & 0.108 \\
\hline 2010-2017 & & & $(0.016)$ & $(0.068)$ \\
\hline In(Employment Density) & & & $0.081^{\star \star *}$ & \\
\hline Change 2010-2017 & & & $(0.027)$ & \\
\hline $\mathrm{R}^{2}$ & 0.039 & 0.035 & 0.060 & 0.023 \\
\hline Observations & 338 & 338 & 338 & 338 \\
\hline
\end{tabular}

Notes: Linear cross-sectional and panel regression analyses - units of analysis are MSAs. NAICS 2-digit industries were used as a basis when computing related-variety measures. Per-capita income is defined as the natural logarithm of total (2017 inflation-adjusted) annual wage and salary income in a MSA divided by total employment. Columns 1 and 2 refer to the growth rates of per-capita income and employment in the 2010-2017 period, columns 3 and 4 to the respective differences. Heteroscedasticity robust standard errors are reported in parentheses. ${ }^{* \star *}$, ${ }^{* \star}$ and * correspond to $p$-values less than $0.01,0.05$ and 0.10 , respectively.

Sources: U.S. Bureau of Economic Analysis (2019), U.S. Bureau of Labor Statistics (2020).

productivity) and employment growth rates. Strikingly, this model closely reproduces key findings of Frenken et al.'s (2007) original study for the United States (although their study covered all regions in the Netherlands, as opposed to just city-regions). Notably Table 3 shows for U.S. MSAs that related variety in the base year is significantly and positively associated with employment growth but not with income (productivity) growth. Moreover, we find that unrelated variety is positively related to income (productivity) growth. While Frenken et al. (2007, p. 696) imply from their findings that "employment policy should stimulate related variety", we believe this implication is less clear. In columns 3 and 4 of Table 3, we use a different model formulation, in which we relate regional development to changes in the independent variables (excluding employment density in column 4). The rationale for this model formulation is to better understand what changes are associated with shifts in development, instead of assuming that development automatically follows from some status in the past. In the reformulated model, related variety change is interestingly not significant, while unrelated variety change is significant at the 10 percent level being negatively associated with income growth. This sug- gests that increases in unrelated variety may be associated with decreases in per-capita income. ${ }^{1}$

While the table suggests that employment (income) growth rates may be linked to cities that have high levels of related (unrelated) variety, this finding does not prove that a causal relationship exists. It could be, for instance, that employment and related-variety levels are correlated but that the industrial mix of related industries in cities has remained relatively stable. ${ }^{2}$ Related variety in that case may not explain changes in employment over time. Such changes may be triggered by different processes. While

1 The results in columns 3 and 4 remained stable a) when looking at the growth rates of independent variables rather than differences over time, b) when running the models with or without log-transformed dependent variables, and c) when conducting the analysis over a much longer time frame from 1993 to 2017. The models were also re-run using NAICS 3-digit and 5-digit industries to compute related-variety measures with the results being the same as before.

2 It should also be noted that both Frenken et al. (2007) and Glaeser et al. (1992) measure increases in income and employment as percent changes (rather than absolute changes), which tend to be biased toward smaller cities with lower initial income and employment levels. 
A)

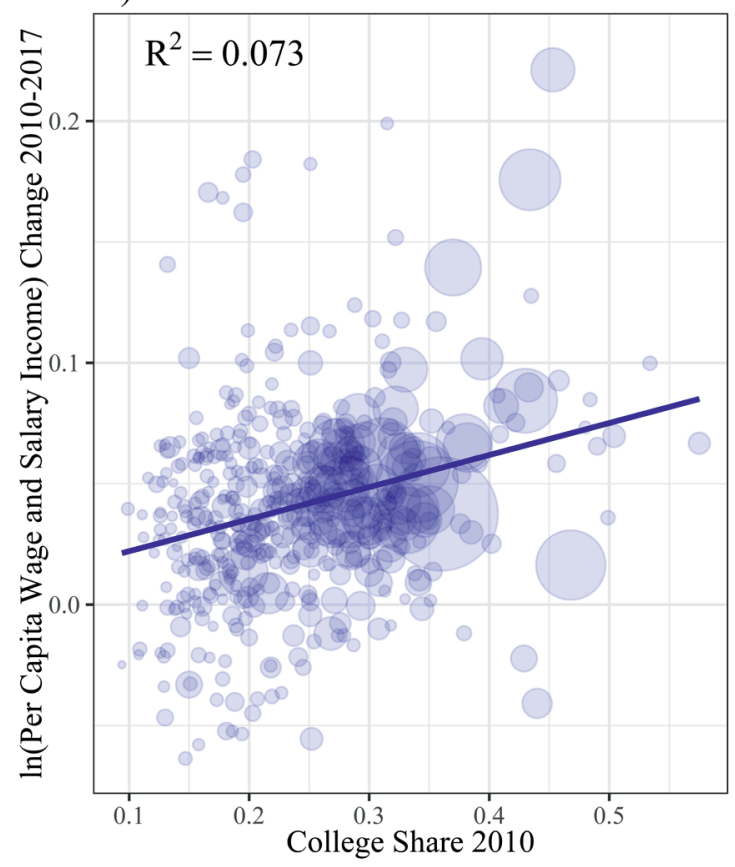

B)



Figure 1: College-Educated Workers (Share) and Per-Capita Income Change in U.S. CBSAs, 2010-2017

Notes: Panel A) uses a similar approach to the models in Tables 1 and 2, showing how College Share in 2010 predicts changes in the natural logarithm of (2017 inflation-adjusted) annual per-capita wage and salary income between 2010 and 2017. Panel B) shows how changes in College Share predict changes in income. Circle size corresponds to a CBSA's total employment.

Sources: American Community Survey (U.S. Census Bureau, 2020), U.S Bureau of Economic Analysis (2019).

we do not disagree with the argument that the nature of an urban area's industrial structure plays a role for future growth opportunities, ${ }^{3}$ a given industrial structure does not necessarily say much about how shifts in economic development are generated and what economic action is responsible for this. This calls for a research program to advance our understanding of underlying processes and to include economic relations across different spatial scales that can trigger development.

\section{Human Capital and Regional Performance}

As with industrial structure, scholars widely agree that differences in human capital are strongly associated with differences in economic development across regions. There are many ways to conceptualize human capital, one of the most common being to use the share of workers with

3 Research on job multipliers, for instance, supports this, showing very heterogenous effects in the extent to which different industries prompt employment growth (Moretti, 2010). a college degree as an indicator. Indeed, when using this indicator, a positive relationship between a region's overall human capital and the level of regional economic development is one of the most consistent results in the literature. Moretti (2004), for instance, found that an increase in the share of college graduates in a city generates increases in nominal wage income for workers across all education levels in that city. It is suggested that increases in the share of college-educated workers can generate income increases for non-college-educated workers if a) non-college-educated and college-educated workers' labor is non-substitutable, such that an increase in the latter elevates the productivity of the former, and b) non-college-educated individuals are able to learn from those who have college degrees (Moretti, 2004). For college-educated workers, co-location with other college-educated workers may facilitate improved quantity and quality of knowledge exchanges, which in turn lead to higher productivity and income levels (Davis \& Dingel, 2019).

Figure 1 shows the corresponding relationship between a city's income and human capital levels (defined here as the share of college-educated workers) for 479 Core-Based Statistical Areas (CBSAs) in the United States. CBSAs are a combination of Metropolitan Statistical Areas (MSAs), 
with an urban core of at least 50,000 people, and micropolitan statistical areas (10,000-50,000 people). Panel A) in Figure 1 shows changes in the natural logarithm of (2017 inflation-adjusted) per-capita wage and salary incomes between 2010 and 2017 over the share of college-educated workers in 2010. This is a model design similar to Glaeser et al. (1992) and Frenken et al. (2007) in Tables 1 and 2. Circle sizes correspond to total CBSA employment in both plots. Panel B) shows changes in the share of college-educated workers and in per-capita income between 2010 and 2017. Like columns 3 and 4 of Table 3, panel B) goes a step further as it relates economic development to changes in the independent variable and not just to a state of the independent variable in the past as in panel A). The positive slopes of the fitted regression lines in both panels in Figure 1 highlight that a) cities with higher shares of college-educated workers in 2010 tended to experience larger improvements in per-capita income between 2010 and 2017 and b) cities with larger changes in their share of college-educated workers generally had bigger shifts in income levels. At the same time, there are clearly substantial outliers in both plots, suggesting that other forces beyond human capital are important determinants for differences in economic development across city-regions.

Consistent with Figure 1, existing research has demonstrated that not only a strong positive relationship exists between regional human capital levels and economic development, but also that the returns to college-educated workers' co-location (within a city-region) may be increasing over time. Cities with high shares of college-educated workers in 1980 have increasingly attracted more college-educated workers over time (Berry \& Glaeser, 2005). This growing concentration has been linked to the growing divergence in average income levels across U.S. cities (Giannone, 2017), as well as to increases in total utility in already high-income cities through endogenous improvements in amenities spurred by the concentration of college-educated workers (Diamond, 2016). Overall, it is widely accepted that the agglomeration of college-educated workers is strongly related to regional economic development, with a much stronger association in those urban areas that are already successful. ${ }^{4}$ However, while a skilled labor force is certainly an important ingredient for

4 It should be noted that there are also other models of regional economic development that focus on human capital. For instance, Florida's (2002) work on the creative class posits that under the conditions of skill shortages in the future, the classic assumption that creative workers move to where job opportunities are (firms' locations) will be reversed and industrial locations will increasingly tend toward cities that have a large reservoir of corresponding talent. successful regions, it is much less clear what mechanisms link this workforce to economic production and how growth is stimulated. A shortcoming of existing models is that the mechanisms and agency behind development are themselves often not investigated.

A key open question in human capital approaches relates to whether the growth of college-educated workers (or a more general shift in human capital) in a city is a cause or an effect of economic development. For instance, Storper \& Scott (2009) suggest that the relationship between human capital levels and regional economic development could either be viewed as a story of jobs moving to people or one of people moving to jobs. In other words, it is important to know whether the migration of workers with high human capital into a city causes economic development or whether in-migration is reflective of deeper underlying processes of job and opportunity creation, which in turn make these cities attractive places to move to. Alternatively, underlying processes and migration patterns may mutually reinforce one another. As in industrial structure approaches, questions regarding the actual causes of development and impulses from outside are crucial for our understanding.

It is generally agreed that the growth of college-educated workers - as well as other types of urban human capital such "creative class" workers (Florida, 2002; 2017) or birthplace-diverse workers (Ottaviano \& Peri, 2006; Buchholz, 2021), will be associated with positive trends in regional economic development (Glaeser \& Gottlieb, 2009). Panel B) in Figure 1 provides support for this argument. However, this is not axiomatic. The growing share of these workers in a city goes along with co-evolutionary processes where new/improved interactions and learning capabilities lead to innovation, economic growth and increased in-migration that elevate urban human capital, in turn creating the possibility for further enhanced interaction and learning capabilities. As with industrial structure, human capital plays a crucial role in regional economic development as it mediates the quality of interactions that can be realized to promote the creation of new technologies and jobs, but only helps to the extent that these interactions are in fact realized. Understanding causality in regional economic development thus requires that we identify and investigate the very mechanisms behind economic growth (Sayer, 1992). Conventional models are often limited in this respect as they associate regional development with localized structures and neglect the potential benefits of dynamic linkages within and across regions or how these contribute to human capital formation. In using a relational perspective in the remainder of this paper to extend and complement other models, we 
will emphasize the potential of such linkages as an indicator of economic actions and interactions that stimulate regional development.

\section{A Relational Perspective of Regional Economic Development}

Studies on regional economic development often employ an explicit evolutionary perspective that aims to investigate the "processes by which the economic landscape [...] is transformed from within over time" (Boschma \& Martin, 2010a: 6f.). This is typically done by identifying those localized structural conditions that affect regional production and innovation (Boschma \& Martin, 2010b). As shown in the previous sections, conventional model designs often investigate the impact of regional structural conditions at one point in time on future development. While it is clear that broad regional structures play a crucial role in shaping the possibilities for future development, the relative lack of attention to the actual mechanisms that trigger this development or how these unfold through linkages at different spatial scales makes such explanations only partial. To include such mechanisms, we apply a relational perspective that investigates how actors (including firms as collective actors) develop networks through which growth impulses are transmitted and collective action mobilized to stimulate economic development (Bathelt \& Glückler, 2011; Glückler, 2013). Specifically, we use a region's connectivity at different spatial scales as an indicator for such economic activities (Bathelt \& Buchholz, 2019; 2021).

While data is not available to measure economic interaction directly and comprehensively across all regions in a country, it is possible to identify specific network structures that span from the local to the global scale. In our analysis of the U.S. urban system, we use firms' subsidiary networks in a city-region as an indicator of the growth triggers that are transmitted to or created within that city-region. These subsidiary networks can be viewed as a long-term infrastructure through which goods, knowledge and human capital are exchanged and linkages created, both locally but also with other regions domestically and internationally. While not the only potential measure of connectivity (Glückler, 2013; Cano-Kollmann et al., 2016), these networks are of fundamental importance to understand how resources and market opportunities are integrated into regional fabrics of production and innovation. Arguably, global subsidiary linkages are associated with the greatest potential to access new technologies and markets, yet they also involve great risks and uncertainties as fundamental institutional differences have to be understood and overcome at that scale (Cantwell et al., 2010; Glückler \& Bathelt, 2017). ${ }^{5}$ While some regions may not have firms that are capable of managing such risks at the global level, these regions' firms may be able to establish domestic linkages that develop within a more homogenous national institutional context where it is easier to create trust (Trippl et al., 2009). Potential gains through extended domestic market access may still be substantial while the potential to access fundamentally new knowledge and market segments may be limited (Li \& Bathelt, 2018). In addition to the international and domestic level, networks at the local level are also of importance to trigger collective action and catalyze regional development potential. Such networks have been at the center of studies on industry agglomeration and clusters for decades (Pyke et al., 1990; Porter, 1990; Bathelt \& Glückler, 2018) and are crucial to implement external knowledge and market opportunities into local production and innovation networks. ${ }^{6}$

An excellent database that enables us to capture firms' subsidiary networks at different spatial scales in the United States is the LexisNexis Corporate Affiliations database, which contains information about ownership hierarchies for the largest public and private firms from 1993 to 2017 (LexisNexis, 2020). In a given year, it contains information for 100,000-400,000 firms. For each firm, we identified the locations of headquarters and majorityowned subsidiaries in city-regions inside the United States (CBSAs) and in other countries. This enabled us to construct comprehensive subsidiary networks and calculate a series of network indicators at the local, national and international levels that capture different channels through which economic growth impulses are transmitted and created. In our model, we used the following variables: 1) Scale is the number of firms in the LexisNexis database located within a CBSA, included to capture potential agglomeration and scale effects that promote knowledge creation and productivity increases; 2) Local Connectivity represents the subsidiary linkages that exist within a CBSA; 3) National Connectivity measures how many other U.S. CBSAs a particular CBSA is connected to through firms' domestic linkages; and 4) International Connectivity captures how many international linkages to foreign-country capitals, global

5 Similar relational understandings of global connectivity have been used across numerous fields of research, including work on world cities, global cluster networks and international trade (Taylor \& Derudder, 2004; Li \& Bathelt, 2018; Venables, 2020).

6 To measure the role of local connectivity more comprehensively would, of course, require going beyond local subsidiary networks and include a wider range of collaborations at this scale (Storper et al., 2015; Ferrary \& Granovetter, 2017). 
Table 4: Relational Model of Per-Capita Income Development in U.S. CBSAs (Core-Based Statistical Areas), 1993 - 2017, Panel Analysis

\begin{tabular}{|c|c|c|}
\hline $\begin{array}{l}\text { Relational Independent } \\
\text { Variables }\end{array}$ & $\begin{array}{l}\text { Model } 1 \\
\text { (1) }\end{array}$ & $\begin{array}{l}\text { Model } 2 \\
\text { (2) }\end{array}$ \\
\hline Scale & $\begin{array}{l}0.022^{\star \star \star} \\
(0.004)\end{array}$ & $\begin{array}{l}0.022^{\star \star \star} \\
(0.004)\end{array}$ \\
\hline Local Connectivity & $\begin{array}{c}-0.009 \\
(0.012)\end{array}$ & $\begin{array}{c}-0.010 \\
(0.014)\end{array}$ \\
\hline National Connectivity & $\begin{array}{l}0.019^{\star \star \star} \\
(0.007)\end{array}$ & \\
\hline National Inward & & $\begin{array}{l}0.018^{\star} \\
(0.010)\end{array}$ \\
\hline National Outward & & $\begin{array}{l}0.020^{\star \star \star} \\
(0.007)\end{array}$ \\
\hline International Connectivity & $\begin{array}{l}0.028^{\star \star \star} \\
(0.009)\end{array}$ & \\
\hline International Inward & & $\begin{array}{l}0.033^{*} \\
(0.018)\end{array}$ \\
\hline International Outward & & $\begin{array}{l}0.021^{\star *} \\
(0.010)\end{array}$ \\
\hline $\mathrm{R}^{2}$ & 0.021 & 0.022 \\
\hline Observations & 22,950 & 22,950 \\
\hline
\end{tabular}

Notes: Linear panel regression analysis - units of analysis are CBSAs. Dependent variable is the natural logarithm of the (2017 inflation-adjusted) annual per-capita wage and salary income in a CBSA. All independent variables were used in logged form. All models include CBSA and year fixed-effects. Heteroskedasticity- and autocorrelation-consistent standard errors are reported in parentheses. ${ }^{\star \star \star},{ }^{\star \star}$ and ${ }^{*}$ correspond to $\mathrm{p}$-values less than $0.01,0.05$ and 0.10 , respectively.

Sources: LexisNexis (2018), U.S. Bureau of Economic Analysis (2019).

cities and other cities a particular CBSA has. National and International Connectivity can also be broken down into inward and outward components, depending on whether subsidiary linkages are directed into or going out of a city respectively. The variables were computed for each year from 1993 to 2017 and all connectivity measures were divided by the number of firms in a CBSA so that they represent connectivity levels relative to a city's overall size.

Table 4 reports panel regressions with and without the split between Inward and Outward Connectivity and estimates the impact of connectivity measures on the logarithm of per-capita wage and salary income in a CBSA. The model includes CBSA and year fixed-effects, meaning that it specifically measures how changes in the independent variables (all used in logged form) affect changes in the dependent variable over time. This is comparable to the models in panel B) of Figure 1 and columns 3 and 4 of Table 3. Compared with many conventional quantitative models that investigate regional development, our approach differs in three important aspects: first, we focus on changes in independent variables that trigger development; second, we measure the actual linkages between actors that stimulate the creation of new technologies and labor demand; and third, we include the impacts of extra-regional linkages on development. The positive signs of all coefficients in Table 4 and their generally low p-values (with the exception of Local Connectivity) demonstrate two points. The first is that it is important to consider the actual linkages between actors (e. g. firms) when modeling development. Economic development is ultimately catalyzed by the actions and interactions of workers, firms and other organizations. The second point is that it is crucial to go beyond the intra-regional level when investigating regional development, as decisive triggers result from extra-regional connectivity and related economic impulses, both domestically and globally. Table 4 shows that urban-regional income levels not only increase in tandem with intra-regional processes (e.g. agglomeration effects) but are also positively impacted by growing domestic and international connectivity in subsidiary networks - with generally higher significance levels for outward compared to inward linkages (Bathelt \& Buchholz, 2019). Overall, these models are robust and demonstrate the utility of a relational approach to regional economic development which considers the actual connections that drive the transmission and creation of knowledge, as well as improvements in productivity (Bathelt \& Buchholz, 2021). The exact nature of these relations at any point in time is a crucial driver for growth and innovation within a city and for changes in development.

Of course, a relational perspective is not at odds with the industrial structure and human capital approaches discussed before. Both can in fact also be formulated and tested in relational terms. Frenken et al. (2007), for instance, suggest that related variety is a proxy for inter-industry knowledge spillovers. However, to conduct a relational approach requires incorporating such linkages in the model designs. Likewise, cities with a larger number of college-educated workers may create improved knowledge exchange environments by giving workers access to better quantity and quality of knowledge, which ultimately elevates workers' productivity and income levels (Moretti, 2004; Davis \& Dingel, 2019). Again, model formulations can be designed to test such relationships.

As will be argued in the next section, even if we were able to capture all different types of linkages between firms (and between their workers) inside and outside their local contexts, there are other significant forces driving disparities in development across regions that depend to a substantial degree on local contexts and institutional settings. These have significant power to generate different development dynamics. 


\section{Geographical Contexts, Institutional Settings and Regional Development}

Despite the significant findings in Table 4, a substantial proportion of changes in per-capita income across cities remains unexplained. While this is visible in the low $\mathrm{R}^{2}$ values in our models with city and time fixed-effects (which are not included in the $\mathrm{R}^{2}$ ), most longitudinal models of regional economic development suffer from similar problems (see Table 3 and Figure 1). As emphasized above, the three approaches reviewed here are complementary, as past structural conditions shape the possibility for social and economic relations to create economic benefits. And yet, even if we were able to measure the density and quality of other types of relationships for many different kinds of actors and how these are mediated by past structural conditions, there would still be significant shifts in development that remain unexplained. This suggests that there are other unknown or difficult-to-measure influences that contribute to changes in regional economic development, resulting in deviations from the predicted development paths or creating new development dynamics. The regularities identified in large-scale macro analyses as in the regression models applied in this paper primarily tell us something about average relationships across a large number of cities and over time. It should not come as a surprise therefore that highly aggregated (i.e. city level) quantitative variables cannot account for specific deviations in development dynamics for each individual region case. However, it is surprising that few studies actually go beyond model regularities and investigate geographical cases at the ground level. Why do some regions confirm or deviate from model regularities and why does this differ?

There is no general answer to what causes large regional economic development residuals, though it is believed that difficult-to-measure and context-specific, institutional factors play an important role (RodríguezPose, 2013). Storper et al. (2015), for instance, find that commonly-cited causes for differences in economic development - such as immigration, cost-of-living, urban human capital, public policies or pure luck - do not do well in explaining the diverging levels of development between the San Francisco and Los Angeles city-regions. Instead, they argue in their study that these differences are due to a combination of inter-organizational and inter-personal networks and institutional settings. Specific contextual conditions may thus explain why certain cities and regions underperform while others overperform in relation to their structural characteristics (Storper, 2009; Bathelt \& Glück- ler, 2018; Clark, 2018; Gong \& Hassink, 2020). This is particularly clear when we investigate the impact of localized institutional contexts on economic action and interaction (Glückler \& Bathelt 2017; Buchholz, 2019). For instance, a city-region may benefit from active local government policies that integrate a broad cross-section of actors into regional economic policymaking (Benner \& Pastor, 2015) or from industry associations that implement networking practices among their local members. All of this may lead to dynamic interaction patterns within a city-region that help overcome structural deficits. And vice versa, the lack of supportive institutional contexts may limit the development potential of other cities.

To illustrate this point, Figure 2 shows variations in income changes for U.S. CBSAs in relation to the predictions of the three different models discussed in this paper: panel A) refers to the industrial structure model (Table 3, column 3), panel B) to the human capital model (Figure 1, panel B) and panel C) to the relational model (Table 4, column 1). Only those CBSAs from each dataset are plotted that experienced average changes in their independent variables for the respective development models (i. e. changes that were within 0.5 standard deviations from the mean change of all independent variables). The changes in income are shown in a standardized form. ${ }^{7}$ If each model provided perfect explanations, we would have expected that income changes would be close to the model predictions. However, we found substantial variation as shown in the box-and-whisker plots in Figure 2 which indicate the 25th, 50th and 75th percentiles of the data and extreme outliers. A large deviation from the predicted income change of ' 0 ' indicates that the underlying model is not capable of explaining regional development well for a particular city-region. The figure indicates that each of the three regional development models makes in many CBSAs good predictions for income development but that the prediction for other CBSAs does not closely mirror actual income changes. It is particularly these cities where it is important to conduct a closer analysis of the contextual and institutional conditions to be able to understand their regional development dynamics, which could be indicative of different development mechanisms.

For example, Odessa, Texas represents an outlier in the relational model in panel C), with much higher increases in income than would have been predicted by the model. This CBSA is heavily structured around the fossil fuel industry and had substantial income increases after the financial crisis from 2010 to 2017 despite only

7 Changes in income were standardized with the mean and standard deviation for each model's entire number of observations. 
A)

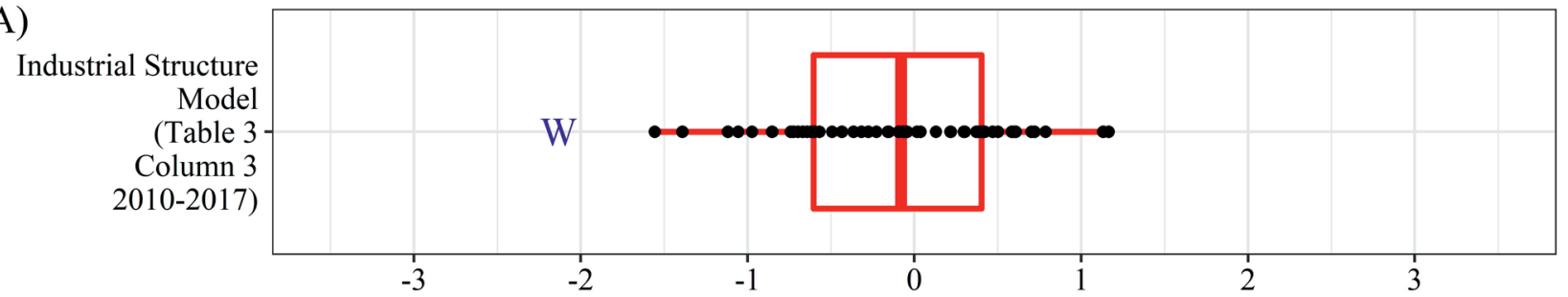

B)

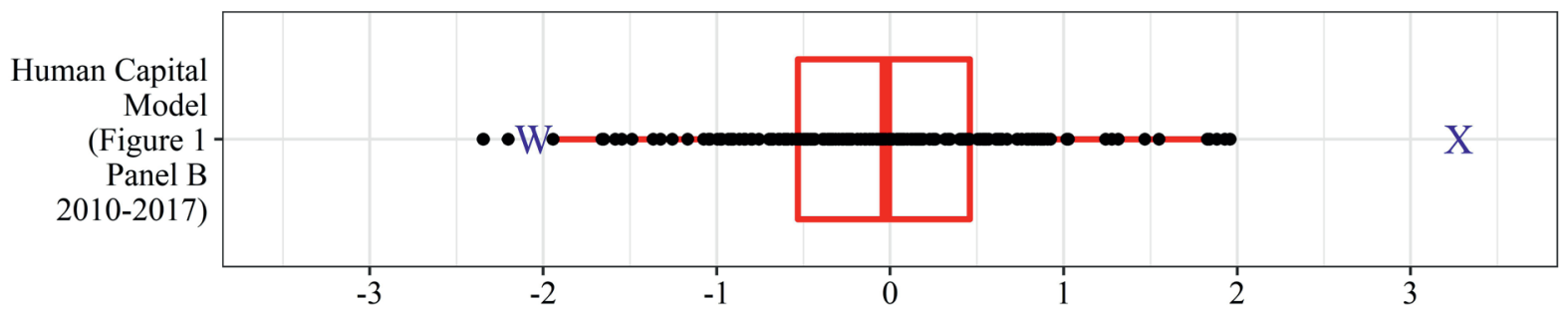

C)

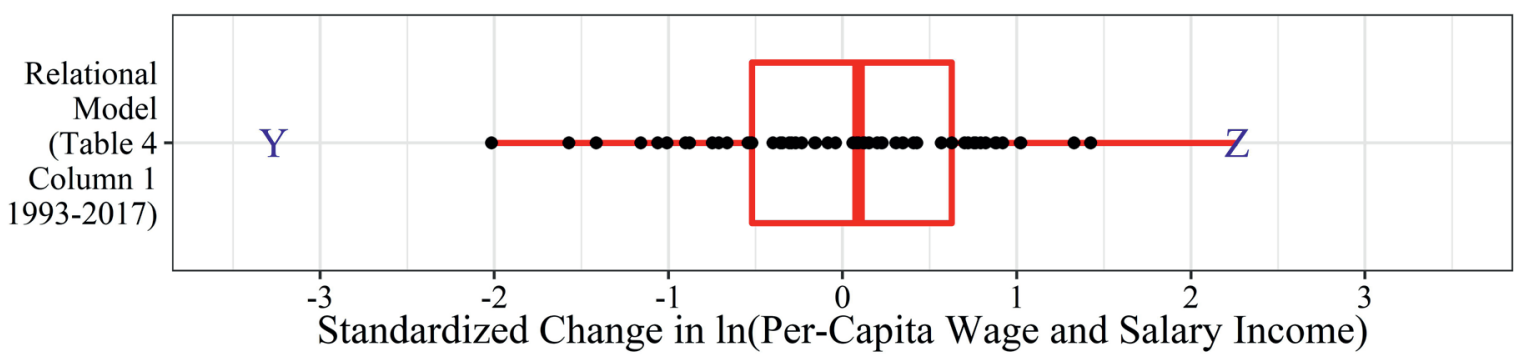

$$
\begin{aligned}
& \mathrm{W}=\text { Bridgeport-Stamford-Norwalk, CT } \\
& \mathrm{Y}=\text { Flint, MI }
\end{aligned}
$$

$$
\begin{aligned}
& \mathrm{X}=\text { Elkhart-Goshen, } \mathrm{IN} \\
& \mathrm{Z}=\text { Odessa }, \mathrm{TX}
\end{aligned}
$$

Figure 2: Boxplots of Deviations in Per-Capita Income Change from Regional Economic Development Model Predictions Notes: Each boxplot corresponds to a different regression model, representing a different approach to explain regional economic development. The U.S. cities shown as dots are those which were characterized by average changes in the independent variables during the observation period for each model (more precisely, cities within -0.5 to +0.5 standard deviations from the mean change). The boxplot shows the actual change in (2017 inflation-adjusted) In(Per-Capita Wage and Salary Income) of these cities in relation to all cities in the corresponding model, measured in standardized form. All analyses were conducted at the level of CBSAs (except for the industrial structure model, where data was only available for MSAs). Selected outlier cities are labeled.

Sources: LexisNexis (2018), U.S. Bureau of Economic Analysis (2019), U.S. Bureau of Labor Statistics (2020), U.S. Census Bureau (2020).

average changes in connectivity levels. However, Odessa experienced a period of economic bust beforehand and thus attempted to branch into other energy sectors and logistics (Federal Reserve Bank of Dallas, 2018). It seems that its specific focus on the fossil fuel industry created a development context that does not follow the linear logic of the models used. In contrast, Flint, Michigan in panel C) illustrates the opposite scenario, where income development lagged behind predicted changes. On the surface, Flint strongly represents the catastrophic effects of deindustrialization processes and its effects on the U.S. automobile industry. And yet, based on the connectivity variables in model 1 of Table 4 we would have expected much higher changes in income than did occur. In Flint, the economic decline went along with a loss in economic diversity (decrease in unrelated variety), persistence of the former industrial structure (slight increase in related variety) and network linkages that clearly lost their capability to stimulate development. Research on deindustrializing cities in the U.S. Rust Belt has pointed to how the structure of civic networks created different capacities for city-regions to mobilize actors and resources and branch into new economic activities (Safford, 2004). Moreover, a number of studies have emphasized the role that racism played in the economic decline in Flint and other deindustrializing U.S. cities (many of which have large Black populations), associated with austerity, private sector divestment, restrictions on local government autonomy and punitive policies aimed at Black people (Pulido, 2016; Hackworth, 2020). 
The human capital model in panel B) reveals that Elkhart-Goshen, Indiana represents a CBSA where the actual increase in per-capita income between 2010 and 2017 was much larger than what was predicted by the model. In other words, the average shift in the share of workers with college degrees does not by itself explain this income growth. Elkhart-Goshen is the self-described "RV [recreational vehicle] capital of the world," a manufacturing industry that is difficult to automate or offshore and that pays high wages for relatively high-skilled jobs that do not require a college degree (Davis, 2018). The city-region fared better in terms of connectivity variables in the relational model (particularly compared with other small CBSAs) and had high location quotients in related manufacturing activities (including boats, wood cabinets, metal products and furniture - U.S. Bureau of Labor Statistics, 2020). This suggests a unique context of local linkages and institutions that make this an attractive manufacturing location and which drives income increases despite little change in human capital levels. A reverse case can be found in Bridgeport-Stamford-Norwalk, Connecticut which was once a significant manufacturing center for shipbuilding, machinery and electric consumer products but suffered from industrial decline during the past half-century (Wald, 1982; Brookings Institution, 2007). Despite having a human capital composition that benefits from being located within the periphery of New York City, and perhaps some remnants of a once advantageous industrial structure, it was apparently not able to overcome its old-industrialized institutional context (having average values of change in the industrial structure model) and trigger significant income growth.

\section{Conclusions}

In pursuing our agenda to better understand and explain regional economic development, we started this paper by emphasizing the need to go beyond models that investigate the impact of broad structural properties and instead consider how cities and regions are embedded in networks of relationships at multiple spatial scales. Structural features like the industrial mix or endowment of human capital in a regional economy are undoubtedly important, as they shape the possibilities for city-regions to develop new capabilities and economic strengths; yet, we criticized that extant approaches to regional economic development overemphasize localized structural features at the expense of the actual dynamic relationships and interactions that lead to the transmission and creation of new knowledge and market access, in turn catalyzing income growth and development. Adopting a relational perspective requires that we consider both linkages within a city-region, as well as extra-local linkages both domestically and internationally. Without these connections that transmit development impulses, we argue, it is less likely that a city with high human capital levels or an advantageous industrial structure will experience significant improvements in development. As illustrated in this paper, common industrial structure variables are associated with city-regions that experience regional economic growth, but shifts in these variables may occur slowly and have heterogenous effects.

While supporting a relational perspective on regional economic development appears to be a step forward, this paper has also argued that comprehensive quantitative models can only identify average relationships between independent and dependent variables but that deviations always exist which are indicative of different development dynamics and logics. The models we discuss are abstract generalizations that do not take into consideration specific sets of contextual and institutional conditions for development. We therefore believe that more emphasis in future research should be placed on conducting systematic comparative studies of cities and regions (Storper et al., 2015; Pike, 2021) that integrate quantitative and qualitative analyses into stylized stories of deviating economic development trajectories. Doing so will enable us to better understand the mechanisms leading to the unfolding of established pathways and the creation of new impulses for economic development. A combination of broad statistical and comparative case-study analyses will also be important from a regional policy perspective, as it will enable policymakers to learn about cross-regional regularities as well as unique local contexts to further economic development. This ought to be particularly important in small, lagging city-regions that are the subject of significant scholarly and public concern, but have received less attention in the regional economic development literature than many larger cities with above-average development levels.

Acknowledgements: Both authors contributed equally to this paper. They would like to thank the anonymous Reviewers and the Editor for constructive criticisms, and Cheryl Cheung, Gilles Duranton, Robert Panitz and Yihan Wang for helpful comments on an earlier draft. Further information about the data used, the relational model and robustness checks can be found in Bathelt \& Buchholz (2021). This research was financially supported by a Social Sciences and Humanities Research Council (SSHRC) Insight Grant (File Number 435-2019-0273). 


\section{References}

Arrow, K.J. (1962) The economic implications of learning by doing. Review of Economic Studies, 29(3): 155-173.

Balland, P.A., Boschma, R., Crespo, J. \& Rigby, D.L. (2019) Smart specialization policy in the European Union: Relatedness, knowledge complexity and regional diversification. Regional Studies, 53(9): 1252-1268.

Bathelt, H. \& Buchholz, M. (2019) Outward foreign-direct investments as a catalyst of urban-regional income development? Evidence from the United States. Economic Geography, 95(5): 442-466.

Bathelt, H. \& Buchholz, M. (2021) A Relational Perspective on Urban Economic Development: Subsidiary Networks and Connectivity. Mimeo, Toronto: University of Toronto.

Bathelt, H. \& Glückler, J. (2011) The Relational Economy: Geographies of Knowing and Learning. Oxford: Oxford University Press.

Bathelt, H. \& Glückler, J. (2018) Wirtschaftsgeographie. Ökonomische Beziehungen in räumlicher Perspektive (Economic Geography. Economic Relations in Spatial Perspective). 4th edn., Stuttgart: UTB - Ulmer.

Bathelt, H. \& Li, P. (2020) Building better methods in economic geography. ZFW (The German Journal of Economic Geography), 64(3): 103-108.

Benner, C. \& Pastor, M. (2015) Equity, Growth, and Community: What the Nation Can Learn from America's Metro Areas. Oakland: University of California Press.

Berry, C.R. \& Glaeser, E.L. (2005) The divergence of human capital levels across cities. Papers in Regional Science, 84(3): 407-444.

Bishop, P. \& Gripaios, P. (2010) Spatial externalities, relatedness and sector employment growth in Great Britain. Regional Studies, 44(4): 443-454.

Boschma, R. \& lammarino, S. (2009) Related variety, trade linkages, and regional growth in Italy. Economic Geography, 85(3): 289-311.

Boschma, R.A. \& Martin, R. (2010a) The aims and scope of evolutionary economic geography. In: Boschma, R.A. \& Martin, R. (eds) Handbook of Evolutionary Economic Geography (pp. 3-39). Cheltenham, Northampton, MA: Edward Elgar.

Boschma, R.A. \& Martin, R. (eds) (2010b): Handbook of Evolutionary Economic Geography. Cheltenham, Northampton, MA: Edward Elgar.

Brookings Institution (2007) Metropolitan Policy Program Restoring Prosperity: Connecticut State Profile. Washington, DC. https://www.brookings.edu/research/ restoring-prosperity-the-state-role-in-revitalizing-americasolder-industrial-cities/ (accessed 18 November 2020).

Buchholz, M. (2019) Organizations, institutions and networks in local scenes: The growth of San Francisco Bay Area punk rock. Geoforum, 103: 158-166.

Buchholz, M. (2021) Immigrant diversity, integration and worker productivity: Uncovering the mechanisms behind "diversity spillover" effects. Journal of Economic Geography, 21(2): 261-285.

Buchholz, M., Bathelt, H. \& Cantwell, J.A. (2020) Income divergence and global connectivity of U.S. urban regions. Journal of International Business Policy, 3(3): 229-248.
Cano-Kollmann, M., Cantwell, J., Hannigan, T.J., Mudambi, R. \& Song, J. (2016) Knowledge connectivity: An agenda for innovation research in international business. Journal of International Business Studies, 47(3): 255-262.

Cantwell, J.A., Dunning, J.H. \& Lundan, S.M. (2010) An evolutionary approach to understanding international business activity: The co-evolution of MNEs and the institutional environment. Journal of International Business Studies, 41(4): 567-586.

Clark, G.L. (2018) Behaviour in context. In: Clark, G.L., Feldman, M.P., Gertler, M.S. \& Wojcik. D. (eds) The New Oxford Economic Geography (pp. 196-212). Oxford: Oxford University Press.

Clark, G.L. (2021) The significance of financial competence and risk tolerance in home-related expenditure by jurisdiction and regime. ZFW (The German Journal of Economic Geography), 65(1): forthcoming.

Content, J. \& Frenken, K. (2016) Related variety and economic development: A literature review. European Planning Studies, 24(12): 2097-2112.

Davis, B. (2018) The future of America's economy looks a lot like Elkhart, Indiana. Wall Street Journal, 14 April. https://www.wsj. com/articles/the-future-of-americas-economy-looks-alot-like-elkhart-indiana-1522942393 (accessed 13 November 2020).

Davis, D.R. \& Dingel, J.I. (2019) A spatial knowledge economy. American Economic Review, 109(1): 153-170.

Dannenberg, P., Braun, B., Fuchs, M. \& Revilla Diez, J. (2018) Dynamics in an unequal world. ZFW (The German Journal of Economic Geography), 62(2): 87-91.

Diamond, R. (2016) The determinants and welfare implications of US workers' diverging location choices by skill: $1980-2000$. American Economic Review, 106(3): 479-524.

Federal Reserve Bank of Dallas (2018) Midland-Odessa: Riding the Oil Booms, Seeking Fewer Busts. Dallas. https://www. dallasfed.org/research/heart/midland.cfm (accessed 18 November 2020).

Ferrary, M. \& Granovetter, M. (2017) Social networks and innovation. In: Bathelt, H., Cohendet, P., Henn, S. \& Simon, L. (eds) The Elgar Companion to Innovation and Knowledge Creation (pp. 327-341). Cheltenham, Northampton, MA: Edward Elgar.

Florida, R.L. (2002) The Rise of the Creative Class: And How It's Transforming Work, Leisure, Community and Everyday Life. New York: Basic Books.

Florida, R.L. (2017) The New Urban Crisis: How Our Cities Are Increasing Inequality, Deepening Segregation, and Failing the Middle Class - And What We Can Do About It. New York: Basic Books.

Frenken, K., van Oort, F. \& Verburg, T. (2007) Related variety, unrelated variety and regional economic growth. Regional Studies, 41(5): 685-697.

Giannone, E. (2017) Skilled-Biased Technical Change and Regional Convergence. Meeting Papers from Society for Economic Dynamics No. 190, Chicago: University of Chicago. https:// home.uchicago.edu/ elisagiannone/files/JMP_ElisaG.pdf (accessed 5 November 2020).

Giddens, A. (1984) The Constitution of Society: Outline of the Theory of Structuration. Cambridge: Polity Press.

Glaeser, E.L. \& Gottlieb, J.D. (2009) The wealth of cities: Agglomeration economies and spatial equilibrium in the United States. Journal of Economic Literature, 47(4): 983-1028. 
Glaeser, E.L., Kallal, H.D., Scheinkman, J.A. \& Shleifer, A. (1992) Growth in cities. Journal of Political Economy, 100(6): $1126-1152$.

Glückler, J. (2013) Knowledge, networks and space: Connectivity and the problem of non-interactive learning. Regional Studies, 47(6): 880-894.

Glückler, J. \& Bathelt, H. (2017) Institutional context and innovation. In: Bathelt, H., Cohendet, P., Henn, S. \& Simon, L. (eds) The Elgar Companion to Innovation and Knowledge Creation (pp. 121-137). Cheltenham, Northampton, MA: Edward Elgar.

Gong, H. \& Hassink, R. (2020) Context sensitivity and economicgeographic (re)theorising. Cambridge Journal of Regions, Economy and Society, 13(3): 475-490.

Hackworth, J. (2019) Manufacturing Decline: How Racism and the Conservative Movement Crush the American Rust Belt. New York: Columbia University Press.

Jacobs, J. (1969) The Economy of Cities. New York: Random House.

Kemeny, T. \& Storper, M. (2015) Is specialization good for regional economic development? Regional Studies, 49(6): 1003-1018.

Kemeny, T. \& Storper, M. (2020) Superstar Cities and Left-Behind Places: Disruptive Innovation, Labor Demand, and Interregional Inequality. LSE International Inequalities Institute Working Paper No. 41. London: London School of Economics and Political Science.

Kubiszewski, I., Costanza, R., Franco, C., Lawn, P., Talberth, J., Jackson, T. \& Aylmer, C. (2013) Beyond GDP: Measuring and achieving global genuine progress. Ecological Economics, 93: 57-68.

LexisNexis (2018). LexisNexis Corporate Affiliations, 1993-2017 [Customized Dataset]. New York. https://www.lexisnexis. com/en-us/products/corporate-affiliations.page (accessed 15 January 2020).

LexisNexis (2020) Global Public \& Private Company Profiles. New York. https://www.lexisnexis.com/en-us/products/ corporate-affiliations/selective-focus-speeds-companyresearch.page (accessed 30 May 2020).

Li, P. \& Bathelt, H. (2018) Location strategy in cluster networks. Journal of International Business Studies, 49(8): 967-989.

Marchand, Y., Dubé, J. \& Breau, S. (2020) Exploring the causes and consequences of regional income inequality in Canada. Economic Geography, 96(2): 83-107.

Marshall, A. (1920) Principles of Economics. 8th edn., London: Macmillan and Co.

Moretti, E. (2004) Estimating the social return to higher education: Evidence from longitudinal and repeated cross-sectional data. Journal of Econometrics, 121(1-2): 175-212.

Moretti, E. (2010) Local multipliers. American Economic Review: Papers and Proceedings, 100(2): 1-7.

Moretti, E. (2012) The New Geography of Jobs. Boston: Mariner Books.

Nijman, J. \& Wei, Y.D. (2021) Urban inequalities in the 21st century economy. Applied Geography: forthcoming.

Ottaviano, G.I.P. \& Peri, G. (2006) The economic value of cultural diversity: Evidence from US cities. Journal of Economic Geography, 6(1): 9-44.

Parnreiter, C. (2018) America first! Donald Trump, the demise of the U.S. hegemony and chaos in the capitalist world-system. ZFW (The German Journal of Economic Geography), 62(1): 1-13.
Pike, A. (2021) Coping with deindustrialization in the Global North and South. International Journal of Urban Sciences, 25: Forthcoming. https://doi.org/10.1080/12265934.2020.17 30225.

Pike, A., Rodríguez-Pose, A. \& Tomaney, J. (eds) (2011) Handbook of Local and Regional Development. London: Routledge.

Porter, M.E. (1990) The Competitive Advantage of Nations. New York: Free Press.

Pulido, L. (2016) Flint, environmental racism, and racial capitalism. Capitalism, Nature, Socialism, 27(3): 1-16.

Pyke, F., Becattini, G. \& Sengenberger, W. (eds) (1990) Industrial Districts and Inter-Firm Co-Operation in Italy. Geneva: International Institute for Labour Studies.

Rodríguez-Pose, A. (2013) Do institutions matter for regional development? Regional Studies, 47(7): 1034-1047.

Romer, P. (1986) Increasing returns and long-run growth. Journal of Political Economy, 94(5): 1002-1037.

Rosenthal, S.S. \& Strange, W.C. (2004) Evidence on the nature and sources of agglomeration economies. In: Henderson, J.V. \& Thisse, J.F. (eds) Handbook of Regional and Urban Economics (Vol. 4, pp. 2119-2171). Amsterdam: Elsevier.

Rutten, R. (2020) Comparing causal logics: A configurational analysis of proximities. ZFW (The German Journal of Economic Geography), 64(3): 134-148.

Safford, S. (2004) Why the Garden Club Couldn't Save Youngstown: Civic Infrastructure and Mobilization in Economic Crises. MIT Industrial Performance Center Working Paper Series No. 04-002. Cambridge, MA: Massachusetts Institute of Technology.

Sayer, A. (1992) Method in Social Science: A Realist Approach. 2nd edn., London: Routledge.

Schmid, B. (2019) Degrowth and postcapitalism: Transformative geographies beyond accumulation and growth. Geography Compass, 13(11): 1-15.

Spicer, J. (2018) Electoral systems, regional resentment and the surprising success of Anglo-American populism. Cambridge Journal of Regions, Economy and Society, 11(1): 115-141.

Storper, M. (2009) Regional context and global trade. Economic Geography, 85(1): 1-21.

Storper, M. (2018) Separate worlds? Explaining the current wave of regional economic polarization. Journal of Economic Geography, 18(2): 247-270.

Storper, M., Kemeny, T., Makarem, N. \& Osman, T. (2015) The Rise and Fall of Urban Economies: Lessons from San Francisco and Los Angeles. Stanford, CA: Stanford University Press.

Storper, M. \& Scott, A.J. (2009) Rethinking human capital, creativity and urban growth. Journal of Economic Geography, 9(2): 147-167.

Taylor, P.J. \& Derudder, B. (2004) World City Network: A Global Urban Analysis. London: Routledge.

Trippl, M., Tödtling, F. \& Lengauer, L. (2009) Knowledge sourcing beyond buzz and pipelines: Evidence from the Vienna software sector. Economic Geography, 85(4): 443-462.

U.S. Bureau of Economic Analysis (2019) Regional Economic Accounts [Dataset]. Washington, DC. https://apps.bea.gov/ regional/downloadzip.cfm (accessed 3 March 2019).

U.S. Bureau of Labor Statistics (2020) Quarterly Census of Employment and Wages-QCEW. QCEW Data Files, 1993-2017 [Dataset]. Washington, DC. https://www.bls.gov/cew/datatoc. htm (accessed 21 May 2020). 
U.S. Census Bureau (2020) Explore Census Data [Dataset]. Washington, DC. https://data.census.gov/cedsci/ (accessed 4 October 2020)

Venables, A.J. (2020) Why some places are left behind: Urban adjustment to trade and policy shocks. Oxford Review of Economic Policy, 36(3): 604-620.
Wald, M.L. (1982) The workplace in transition. New York Times, 5 September. https://nyti.ms/29yStXL (accessed 18 November 2020).

Zhu, S., He, C. \& Zhou, Y. (2017) How to jump further and catch up? Path-breaking in an uneven industry space. Journal of Economic Geography, 17(3): 521-545. 